\title{
ANALYSIS OF VILLAGE REGULATION BASED ON LAW NO. 6 OF 2014 CONCERNING VILLAGE, IN THE VILLAGE OF ESANDOM ONE DISTRICT MINAHASA TENGGARA
}

\author{
Jolly Turangan, Kiet Tumiwa, Angela M. Koloay, Farida I. S. Wakidin \\ Department Of Accounting, Polytechnic of Manado Country \\ DOI: $10.31364 / S C I R J / v 7.110 .2019 . P 1019 X X$ \\ http://dx.doi.org/10.31364/SCIRJ/v7.i10.2019.P1019XX
}

\begin{abstract}
The purpose of this research is to find out the implementing regulations of Law No. 6 of 2014 that have existed until now, namely the technical regulation of Regulation of the Minister of Home Affairs Number 113 of 2014 concerning village financial management, which is transparent, accountable, participatory, and carried out in an orderly and budgetary discipline. This research is normative juridical, which is examining the principles of law, legal principles and systematics of law. Data obtained by library research and field research. Literature research is intended to obtain secondary data, while field research is intended to obtain primary data to support secondary data. Based on the results of research that Esandom Village One has implemented Regulation of the Minister of Home Affairs Number 113 of 2014 well based on transparent, accountable, participatory principles, and is carried out in an orderly and budgetary discipline in terms of village financial management, which is illustrated in the implementation of village finance that explains how development in Esandom Village one has been carried out in accordance with applicable regulations.
\end{abstract}

Keywords: Management Finance Village

\section{INTRODUCTION}

Law Number 6 of 2014 concerning villages. Villages are given a great opportunity to manage their own governance and implementation of development to improve the welfare and quality of life of rural communities. In addition, the village government is expected to be more independent in managing the government and various natural resources they have, including the management of village finances and assets. Such a large role is accepted by the village, of course accompanied by great responsibility as well. Therefore, the village government must be able to apply the principle of accountability in its governance, where all the final activities of village governance must be accountable to the village community in accordance with the provisions.

Law Number 6 of 2014 concerning villages, it is hoped that all the interests and needs of rural communities can be better accommodated. Providing greater opportunities for villages to manage their own governance, as well as equitable implementation of development is expected to improve the welfare and quality of life of rural communities, so that problems, such as disparities between regions, poverty, and other socio-cultural problems can be minimized. However, the limited resources of the village community regarding legal knowledge is an obstacle in understanding Law No. 6 of 2014 concerning villages which became the basis for drafting village regulations. There are still villages in Southeast Minahasa District that do not yet have adequate village regulations that meet the standards for legal drafting. In addition, Article 69 paragraph (9) states that the draft village regulation must be consulted with the village community.

The large role accepted by each village, of course, is accompanied by a great responsibility as well. Therefore, the village government must be able to apply the principles of accountability in the form of transparent, accountable, participatory, and carried out in an orderly, and disciplined budget in its governance, which is regulated in Regulation of the Minister of Home Affairs Number 113 of 2014 concerning village financial management. In the case of village finances, the village government is required to prepare a Report on the implementation of the budget, and the budget for village revenue and expenditure, and the budget realization accountability report. This report is produced from a cycle of village financial management, which starts from the stages of planning and budgeting; implementation and administration; to reporting and accountability for village financial management.

However, the roles and responsibilities received by the village have not been matched by adequate human resources in terms of both quantity and quality. Other common constraints, namely the village does not yet have procedures and support of facilities and infrastructure in its financial management, and the community has not been critical of the management of village income and expenditure budgets. The amount of funds that must be managed by the village government has a high enough risk in its management, especially for village government officials. The phenomenon of regional officials involved in legal cases should 
not be repeated on the scale of the village administration. Village government apparatuses and village communities represented by the village consultative body must have an understanding of the legislation and other provisions, and have the ability to carry out recording, reporting and accountability.

Based on the above background, it is obligatory for each village to have village regulations. Therefore, researchers are interested in researching and knowing village regulations that have been prepared based on the principles of village financial management as stipulated in Regulation of the Minister of Home Affairs Number 113 of 2014, namely transparent, accountable, participatory and carried out in an orderly and disciplined budget

\section{RESEARCH METHODS}

This research is normative juridical, which is examining the principles of law, legal principles and systematics of law. Data obtained by library research and field research. Literature research is intended to obtain secondary data, while field research is intended to obtain primary data to support secondary data. The results of the research will be analytical descriptive in order to obtain a detailed and systematic picture of various aspects of law relating to village regulations.

\subsection{Literature Research}

A. Data in the form of:

Primary legal material

a) Law No. 6 of 2014 concerning villages

b) Ministerial Decree

c) Ministerial regulations

1. Secondary Legal Materials

Legal material that provides an explanation of primary legal material in the form of literature on state administrative law and state administrative law relating to village issues, namely:
a. Book
b. Paper
c. Article
d. a journal

2. Tertiary Legal Materials

Namely legal materials that provide standard explanations on primary and secondary legal materials in the form of:

\section{B.}

a. Dictionary of legal terms

b. Indonesia dictionary

The research tool is the study of documents. You do this by studying the set of regulations, and other materials selected according to the object of research. Then, the material is sought for its legal basis, in the form of legal norms, and positive legal provisions which form the basis of the compilation of village regulations.

\subsection{Field Research}

\section{A. Data}

Field research data is primary data that supports secondary data. How to obtain primary data by determining the location of research and research subjects.

1. Research Location

Research location in Esandom Village Satu

2. Research Subjects

The research subjects consisted of respondents and resource persons

a. Respondents

- Village head

- Chairperson of the village consultative body

b.Narasumber

\section{- Public figure}

2. Data Collection Method

Data collection methods to determine respondents using purposive sampling, namely the determination of the sample is not random or (non-rendem) carried out based on the criteria and considerations in accordance with the researchers' own knowledge in line with the research problem.

B. Research Tools

The research tool that will be used is an interview using interview guidelines. 
This research will be carried out with the following stages:

1. Preparation

Preparation begins with pre-research activities in the form of collecting material related to the object of writing, then identified and relevant written or used as library material. In addition, establishing relationships with speakers. The next step is the preparation and submission of research proposals to obtain the approval of the head of the research Center, and community service. Furthermore, preparation of interview guidelines, and making permits with research related parties.

2. Implementation

The research was carried out in the form of reviewing library data, namely primary, secondary and tertiary legal materials, followed by field research in the village. To obtain information needed by respondents, and informants as a source of primary data.

3. Settlement

Legal materials that have been obtained both primary and secondary data are selected, and which are relevant to research. Then, analyzed qualitatively. Next, conclusions are drawn using deductive and inductive methods as needed. The results of this study will be analytical descriptive, in order to obtain a detailed and systematic picture of various legal aspects relating to the preparation / making of Esandom village regulations.

\section{DISCUSSION}

With the passage of Law No. 6 of 2014 concerning villages, villages are given a great opportunity to take care of their own governance, as well as the implementation of development to improve the welfare and quality of life of rural communities. In addition, the village government is expected to be more independent in managing the government, and various natural resources owned, including financial management, and village property. Such a large role is accepted by the village, of course accompanied by great responsibility as well. Therefore, the village government must be able to apply the principle of accountability in its governance, where all the final activities of village administration, must be accountable to the village community in accordance with the provisions.

Implementing regulations of Law Number 6 of 2014 that have existed until now, namely Government Regulation Number 43 of 2014 concerning Villages, Government Regulation Number 60 of 2014 concerning village funds sourced from the state budget, as well as several technical rules from the Ministry of Home Affairs including, namely Regulation of the Minister of Home Affairs Number 113 of 2014 concerning village financial management. It is hoped that with the passing of Law No. 6 of 2014 concerning Villages, all interests and needs of village communities can be better accommodated. Providing greater opportunities for villages to manage their own governance, as well as equitable implementation of development is expected to improve the welfare and quality of life of rural communities, so that problems such as disparities between regions, poverty, and other socio-cultural problems can be minimized. Law Number 6 of 2014 and its implementing regulations have mandated the village government, to be more independent in managing the government, and various natural resources owned, including financial management and assets belonging to the village.

The big role accepted by the village, of course, is accompanied by a great responsibility as well. Therefore, the village government must be able to apply the principle of accountability in its governance, where all the final activities of village governance must be accountable to the village community in accordance with the provisions. In the case of village finances, the village government is obliged to prepare a Report on the implementation of the village revenue and expenditure budget and accountability report on the realization of the implementation of the village revenue and expenditure budget. This report is produced from a cycle of village financial management, which starts from the planning and budgeting stages; implementation and administration; to reporting and accountability for village financial management. In the planning and budgeting stages, the village government must involve the village community, represented by the Village Consultative Body, so that the work programs and activities prepared can accommodate the interests and needs of the village community, as well as in accordance with the capabilities of the village. In addition, the village government must be able to keep records, or at a minimum keep a record of its financial transactions as a form of financial accountability it does.

However, the roles and responsibilities accepted by the village have not been matched by adequate human resources in terms of both quantity and quality. Other common constraints, namely the village does not yet have procedures, as well as the support of facilities and infrastructure in its financial management, as well as the community's lack of critical management of the revenue budget and village shopping. The amount of funds that must be managed by the village government has a high enough risk in its management, especially for village government officials. The phenomenon of regional officials involved in legal cases should not be repeated on the scale of the village administration. Village government officials, and village communities represented by the Village Consultative Body must have an understanding of the laws and regulations and other provisions, and have the ability to carry out recording, reporting and accountability. Therefore, as mandated in the village law, the government, provincial government, and district / city government helped to empower village communities by providing assistance in planning, implementing, and monitoring village development. The Government Financial Examination Board, as the mandate to accelerate the improvement of the quality of state financial accountability as stated in the fourth dictum of Presidential Instruction Number 4 of 2011 concerning the acceleration of quality improvement of state financial accountability, took the initiative to prepare Guidance for guidance implementation and village financial management consultation. 
Profile of Esandom Village One is one of the villages located in East Tombatu District, Southeast Minahasa District which has an area of approximately 125 kilometers. Esandom Village One itself is the result of the division of villages in 2010, which was formerly still called Esandom Raya, after the issuance of the Southeast Minahasa District Regulation No. 20/2009 concerning the formation of villages in Southeast Minahasa District, because at the time of the pemekaran there were no village head elections, then appointed officials or executors of tasks by the district, namely Mr. Jhony Ratuela. In 2013 the village of Esandom Satu was led by the Law of the Elder / elected Village Head, Mr. Ferni Rondonuwu until April 2019. The Esandom Satu village consisted of 4 guards / neighborhoods, with a total population of 747 people, 630 people who already had a Card Identity Cards and 117 people who do not have a National Identity Card (including children under 17 years of age) until April 2019.

In the village financial management cycle, the responsibilities and duties of the village head, and the village financial management technical implementer. Technical implementers in village financial management, consisting of:

a. Village head

The main tasks and functions of the Village Head are as follows:

1. Carrying out Village Government, such as governance of the government, stipulation of regulations in the village, fostering land issues, fostering peace and order, carrying out efforts to protect the community, population administration, structuring and management of the area

2. Carry out development, such as rural infrastructure development, and development of education, health.

3. Community development, such as the implementation of community rights and obligations, community participation, community socio-cultural, religious, and employment.

4. Community empowerment, such as the task of socialization and community motivation in the fields of culture, economy, politics, environment, family empowerment, youth, sports, and youth organizations.

5. Maintaining partnership relations with community institutions and other institutions.

b. Village secretary

1. Carry out administrative matters such as manuscripts, administration of correspondence, archives, and expeditions.

2. Carry out public affairs such as structuring administration of village apparatus, providing infrastructure of village apparatus and offices, preparing meetings, administering assets, inventorying, official travel, and public services.

3. Carry out financial affairs such as administration of financial administration, administration of income and expenditure sources, verification of financial administration, and income administration of the village head, village officials, village consultative body, and other village government institutions.

4. Community empowerment, such as the task of socialization and community motivation in the fields of culture, economy, politics, environment, family empowerment, youth, sports, and youth organizations.

5. Carry out planning matters such as preparing village revenue and expenditure budget plans, inventorying data in the framework of development, monitoring and evaluating programs, and preparing reports.

6. Carry out other tasks given the old law.

c. Village Consultative Body

1. Discuss and agree on the village regulation draft with the village head.

2. Accommodating and channeling the aspirations of rural communities.

3. Monitor the performance of the village head.

d. Section Chief

1. Carry out governance management of the government, compile the draft village regulations, foster land issues, foster peace and order, the implementation of community protection efforts, population, territorial arrangement and management, as well as data collection and management of village profiles.

2. Carry out activities and / or with village community institutions that have been set in the village budget.

3. Take actions that cause the burden of activity expenditure budge

4. Controlling the implementation of activities.

5. Report the progress of the implementation of activities to the village head.

e. Head of Financial Affairs

1. Assist the village secretary in carrying out management of village income sources, management of village financial administration.

2. Preparing materials for the compilation of village budget and village expenditures.

3. Carry out other tasks given by the village secretary.

f. Head of General Affairs

1. Assist the village secretary in carrying out general administration

2. Administration of archives.

3. Management of village wealth inventory

4. Prepare meeting agendas and reports.

5. Implement, control and manage incoming and outgoing letters, as well as archival control.

g. Head of Planning

1. Assist the village secretary in administrative services, as well as supporting planning for the implementation of government tasks.

2. Coordinating planning affairs, namely preparing an income budget plan, and village shopping.

3. Inventory data in the framework of development.

4. Monitoring and evaluating programs for the preparation of reports. 
h. Head of the Environment

1. Assist and carry out the duties of the Village Head in his working area.

2. Carrying out government administration activities, and development.

3. Implement decisions and policies of the village head

4. Assist the Village Head in the activities of fostering and harmony of citizens.

5. Help improve self-help and mutual cooperation.

6. Carry out coaching for village government programs.

7. Carry out other tasks given by the Village Head

I. Financial Implementation of Esandom Village One

a. Preparation of Budget Plans

The procedure, or the flow of preparing the Esandom Village budget and budget plan, is as follows:

Preparation and Approval of the Budget Plan

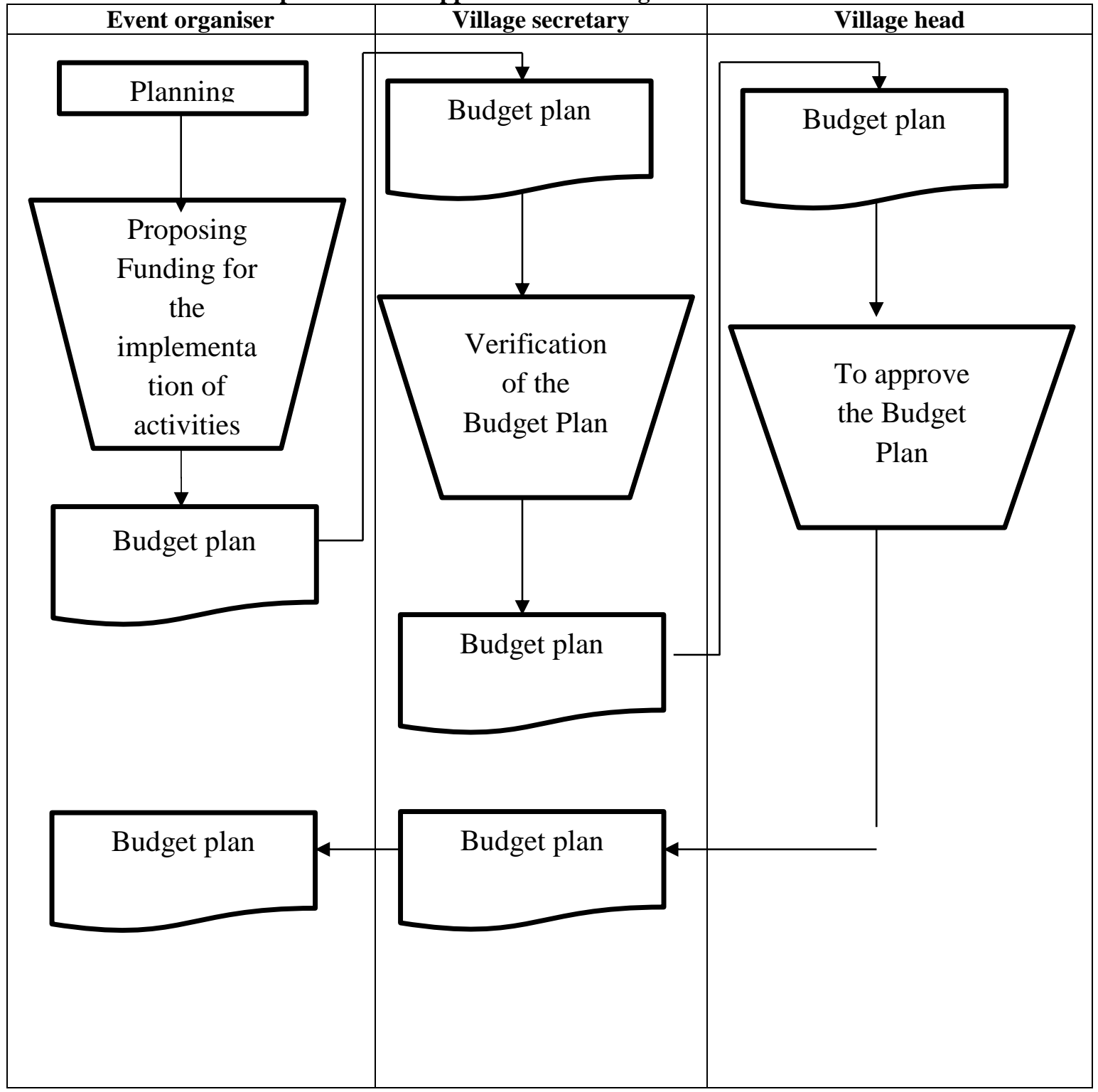

As illustrated in the compilation flow, and the approval of the Cost Budgeting Plan above, that the implementer of the activity will propose funding for the implementation of the budgeting activities, both for village development, or payment of fixed income, and benefits made on the basis of planning. After that, the Budget Plan is made and submitted to the Village Secretary for evaluation, and after the evaluation will be immediately submitted to the Village Head for endorsement. Furthermore, the budget plan is returned to the implementing activity. Furthermore, it is used as an introduction for making a Payment Request. Below is the Esandom Village Budget and Expenditure Plan one, in stage One. After making this budget and expenditure plan, the activity implementer will produce a payment request letter.

b. Payment Request Letter 
From the preparation and approval of the budget plan, the activity organizer will produce a Request for payment. In the procedure for submitting the request for payment above, explaining that from the budget plan that has been approved previously will be made a document in making the request for payment, in making the Request for Payment is supported by proof of transaction, and expenditure statement documents. Then, the documents are verified by the Village Secretary and after verification will be submitted to the Village Head for approval of the payment request, and will be submitted to the Village Treasurer for payment and attach the Proof of payment. Then the proof of Payment document will later be brought to the Village Financial Administration.

c. Valid and Complete Proof

As explained earlier, this valid and complete evidence is a supporting document that contains transaction data that is made after making a transaction, and is used for recording purposes. The evidences are in the form of general cash book, bank book, Tax assistant book.

d. Receipt and Taxation

Receipt is one proof of expenses paid to third parties, if there is a deduction or tax obligation, then the tax report must be attached together with the receipt.

e. Report on Realization of the Implementation of Village Budget and Revenue

Realization Report on the Implementation of Revenue Budget, and this village expenditure is a form of accountability report for all activities in the implementation of the revenue budget and village expenditures which result in income generation, and expenditure activities related to the implementation of village finances. From this report can measure the extent of the implementation carried out. And Esandom Village has been accounted for through the report

\section{Village Financial Management Principles}

The Regulation of the Minister of Home Affairs Number 113 of 201, village financial management must be based on transparent, accountable, participatory principles, and carried out in an orderly and budgetary discipline.

\section{a. Transparent Principle}

Transparent can be interpreted as the nature of openness, or things that are not hidden, or kept secret in the management of village finances, and can be known and even monitored by other authorized parties. In the management of village finance the term transparent has the understanding, that the financial information aspect is given openly, and honestly to the community, in order to fulfill the public's right to know openly, and comprehensively the responsibility of the government in managing the resources entrusted, as well as adherence to the laws and regulations. .

If the principle of transparency is underestimated by the village government, things will be deviated from the rules. For example, if there is a lack of transparency in financial management, the village financial administration will not be organized properly, there will be a certain flow of funds (funds that are not actually included in the budget), which are only known by a handful of people so that the community does not know these things. This will certainly have a negative impact other than the community will have fatal consequences later on when the accountability of village financial reports.

For this reason, the principle of transparency in the management of village finances is needed, and guarantees the right of all parties to know the entire process at each stage of relevant information. Thus, the village government can make it easy for anyone, at any time to access, or know information related to village financial management. Because according to Regulation of the Minister of Home Affairs Number 113 of 2014 article 40 paragraph (1) that the accountability report for the implementation of the Revenue Budget, and Village Expenditure is informed to the community in writing, and with information media that is easily accessed by the community.

The researcher obtained the results of the interview, where village financial management has fulfilled the nature of transparency, the proof is that now every reporting of incoming village funds, for the current period has been made in the form of a notice board, this applies to all villages in North Minahasa Regency. In this connection, the community can find out how much budget the Esandom Village gets in one year. Not only that, the village government must also make a report on the realization of the budget that has been used. Then mounted on the bulletin board. This is done so that there is no skewed response from the community about village financial management, so that public trust in village financial management is increased. Likewise, village financial management that has used an application, for Esandom Village, one that has applied an application, in early 2017. This has had a very good impact on village financial management, which supports the nature of transparency. All transactions entered can be directly accessed by the authorities, namely the local government and even the central government. For the time being the village website is also being developed.

In this village website, it will make it easier for the community to access everything related to Esandom Village's financial one. So, not only the central government, and the regions can access it, but also the public can access it through the existing website. Thus, Esandom Village One has fulfilled Regulation of the Minister of Home Affairs Number 113 of 2014 concerning the principles of village financial management, namely the principle of transparency.

b. Accountable Principle

Accountability is the provision of information, and disclosure of government financial activities and performance to interested parties. Accountability means that every activity or action of the regional government, or village government must be accountable to those who have the right to ask for accountability.

This principle requires the Village Head to report accountability for the implementation of the Revenue Budget and Village expenditures properly and correctly, in an orderly manner to the community as well as to the above levels of government, in accordance with statutory regulations. As explained above, from the results of research that the village of Esandom is one in 
this case, the village government has carried out what has become an obligation, in fact every village financial management, must and must be reported or made accountable annually, posted on the village bulletin board, even handed over to the district head who will be signed by the Regent. Whenever there is a village development activity, the government is obliged to attach the activity boards along with the budget, this shows the attitude of responsibility of the village government.

\section{c. Participatory Principle}

The Participatory Principle is more about community participation, or direct involvement of village communities directly or indirectly, through representative institutions that can channel their aspirations. For example in the village of Esandom One a Village Consultative Body has been formed, which has the task and function as an indirect absorber of community aspirations, while for the case of direct involvement of the village community, in village development is mutual cooperation. In terms of making village facilities and infrastructure. This activity will certainly have a positive impact on the village government and even the people in Esandom Village One.

\section{d. Orderly Principleand Budget Discipline}

Orderly and budgetary discipline means that the budget must be carried out consistently with records that are in accordance with applicable village financial accounting principles. Likewise, in the village of Esandom one, from the results of the study all the accountability reports that exist both budget revenue and village expenditure in which the Village Fund and Village Fund Allocation has been carried out in accordance with the applicable Law in this case the Village Regulation, and is reported at the end of each year, or every 31 December. And this accountability report before being submitted to the district level local government, is first checked, or signed by the auditor entrusted by the district government. After the village financial report is completed, approximately one week will be submitted to the auditor. Then, it was signed, after which it was handed over to the sub-district head for approximately three days, then handed over to the regional government or regent. This is a form of adherence and discipline to the budget of the village government in managing village finances. Village financial management is certainly an obligation of every village government, even the people in Esandom village, one of which is a big responsibility, and requires enthusiasm, hard work and even collaboration of related parties.

\section{Power of Village Financial Management}

In managing village finances, the Village Head is the authority in carrying out village financial management, which is assisted by the Village Financial Management Technical Implementer, who is appointed by the Village Head. The Village Head, besides being the government, also represents ownership of the separated village wealth. Meanwhile, according to Regulation of the Minister of Home Affairs Number 113 of 2014, the power of financial management rests with the Village Head assisted by the Village Secretary, Section Head and Treasurer. From the observations of researchers, the village of Esandom has a designated treasurer. However, for the affairs of village financial administration it is still held by the Head of Financial Affairs, which is actually the Head of Financial Affairs. 113 of 2014 Technical Implementation of Village Financial Managers. In this case, the one who actually takes care of all village financial administration is the Treasurer, not the Head of Financial Affairs.

\section{CONCLUSION}

Based on the results of research in the field, and adjustments to the theory found that Esandom Village One has implemented Regulation of the Minister of Home Affairs Number 113 of 2014 well which, based on transparent, accountable, participatory principles, and is carried out in an orderly and budgetary discipline in terms of village financial management , which is illustrated in the implementation of village finances, which explains how development in Esandom Village One has been carried out in accordance with applicable regulations.

The principle of transparency, is defined as the nature of openness or matters that are not kept secret in the financial management of Esandom Village One, and even overseen by other authorized parties. For financial information is given openly, and honestly to the public in order to fulfill the public's right to know openly and comprehensively the responsibility of the government in the management of entrusted resources as well as compliance with laws and regulations.

The Accountable Principle, this principle requires the Village Head to report accountability for the implementation of the Revenue Budget and Village Expenditure properly, properly in an orderly manner to the community and government officials above it in accordance with statutory regulations. As explained above, from the results of research that the village of Esand om is one in this case the village government has carried out what has become an obligation, in fact every village financial management must and must be reported, or made accountability every year posted on the village bulletin board even submitted to the district head who will be signed by the Regent. And this has become an absolute task of the Esandom village government one.

The Participatory Principle, is more about the community's participation or direct involvement of the village community both directly and indirectly, through representative institutions that can channel their aspirations. Desa Esandom one has formed a Village Consultative Body that has the task, and functions as a channel for indirect community aspirations, while for direct involvement of village communities in village development is mutual cooperation in the manufacture of village infrastructure and facilities. This activity will certainly have a positive impact on the village government, even the people in Esandom Village one.

Orderly and budgetary discipline, having the understanding that the budget must be carried out consistently with records that are in accordance with applicable village financial accounting principles. Likewise, in the village of Esandom one, from the results of the study all the accountability reports that exist both the Village Budget and Income in which the Village Fund Allocation and Village Fund have been carried out in accordance with the applicable Laws in this case the Village Regulations, and reported every end year or every December 31.

\section{REFERENCES}


Government Finance Audit Board, 2015. Guidance for Guidance and Village Financial Management Consultation. Huda, Miftahul dan Nazriyah. 2011. Theory and Testing of Regulations.. Bandung: Nusa Media.

Muhammad, Abdul Kadir. 2004. Law and Legal Research.

Mahendra P. K., dkk. 2007. Participatory Regional Regulation Academic Paper Guidelines, Yogyakarta : Kreasi Total Media. Law of the Republic of Indonesia Number 23 of 2014 concerning Regional Government.

Law of the Republic of Indonesia Number 6 of 2014 concerning Villages

Republic of Indonesia Law Number 12 of 2012 concerning Formation of Regulations and Regulations.

The Regulation of the Minister of Home Affairs Number 113 of 2014

The Regulation of the Minister of Home Affairs Number. 29 of 2006 concerning Guidelines for the Formation and Mechanism of Village Regulation Formulation 